\title{
A residue free approach to water disinfection using catalytic in situ generation of reactive oxygen species.
}

Thomas Richards ${ }^{1}$, Jonathan H. Harrhy ${ }^{1}$, Richard J. Lewis ${ }^{1}$, Alexander G. R. Howe ${ }^{1}$, Grzegorz M. Suldecki ${ }^{2}$, Andrea Folli ${ }^{1}$, David J. Morgan ${ }^{1,3}$, Thomas E. Davies ${ }^{1}$, E. Joel Loveridge ${ }^{1,4}$, David A. Crole ${ }^{1}$, Jennifer K. Edwards ${ }^{1}$, Paul Gaskin ${ }^{5}$, Christopher J. Kiely ${ }^{1,6}$, Qian $\mathrm{He}^{7}$, Damien M. Murphy ${ }^{1}$, Jean-Yves Maillard ${ }^{2}$, Simon J. Freakley ${ }^{8}$ and Graham J. Hutchings ${ }^{1 *}$

${ }^{1}$ Cardiff Catalysis Institute, School of Chemistry, Cardiff University, Main Building, Park Place, Cardiff, CF10 3AT, UK

${ }^{2}$ Cardiff School of Pharmacy and Pharmaceutical Sciences, Cardiff University, Cardiff, CF10 $3 \mathrm{NB}, \mathrm{UK}$

${ }^{3}$ HarwellXPS, Research Complex at Harwell (RCaH) Didcot, OX11 0FA, UK

${ }^{4}$ Department of Chemistry, Swansea University, Singleton Park, Swansea, SA2 8PP, UK

${ }^{5}$ Dŵr Cymru Welsh Water, Pentwyn Road, Nelson, Treharris, CF46 6LY, UK

${ }^{6}$ Department of Materials Science and Engineering, Lehigh University, Bethlehem, PA 18015, USA

${ }^{7}$ Department of Materials Science and Engineering, National University of Singapore, 9 Engineering Drive 1, EA 03-09, Singapore, 117575

${ }^{8}$ Department of Chemistry, University of Bath, Claverton Down, Bath, BA2 7AY, UK

*Corresponding Author - Hutch@cf.ac.uk 


\begin{abstract}
.
Globally, water disinfection is reliant on chlorination but a route that avoids the formation of chemical residues would be preferred. Hydrogen peroxide, can offer such an alternative, is a broad-spectrum biocide but typically is less effective than traditional approaches to water remediation. Here, we show that the reactive species - including hydroxyl, hydroperoxyl and superoxide radicals - formed over a AuPd catalyst during the synthesis of hydrogen peroxide from hydrogen and air are over $10^{7}$ times more potent than an equivalent amount of pre-formed hydrogen peroxide and over $10^{8}$ times more effective than chlorination under equivalent conditions. The key to bactericidal and virucidal efficacy is the radical flux that forms when hydrogen and oxygen are activated on the catalyst. This approach can form the basis of an alternative method for water disinfection particularly in communities not currently served by traditional means of water remediation or where access to potable water is scarce.
\end{abstract}




\section{Introduction}

Hydrogen peroxide $\left(\mathrm{H}_{2} \mathrm{O}_{2}\right)$ has applications as a disinfectant and is produced on an industrial scale using an indirect process in which anthraquinone carrier molecules are utilised to prevent mixing of $\mathrm{H}_{2}$ and $\mathrm{O}_{2}$ feeds. ${ }^{1}$ There has been considerable interest in designing a direct process and progress has been made using dilute $\mathrm{H}_{2}$ and $\mathrm{O}_{2}$ mixtures below the lower explosion limit), ${ }^{2}$ with Pd-based catalysts highly effective, although catalytic activity is markedly enhanced when alloyed with Au. ${ }^{3-5}$ This synergistic effect has been noted with AuPd alloy compositions prepared using a range of methods and on many supports. ${ }^{6,7}$ As reported by Wilson and Flaherty, the reaction pathway is considered to involve a sequential proton-electron transfer to surface bound species $\left(\mathrm{O}_{2}\right.$ and $\left.\mathrm{OOH}\right)$ whereas the unselective production of $\mathrm{H}_{2} \mathrm{O}$ results from $\mathrm{O}-\mathrm{O}$ bond cleavage. ${ }^{8}$ Further theoretical studies by $\mathrm{Li}$ et al. ${ }^{9}$ have shown that the alloying of $\mathrm{Pd}$ with $\mathrm{Au}$ is able to promote the release of $\mathrm{H}_{2} \mathrm{O}_{2}$ from Au-Pd surfaces and have led to the suggestion that, in a similar manner but to a far lesser extent, Au may promote the desorption of surface bound intermediate species, such as $\mathrm{OH}$ and $\mathrm{OOH}$, into solution.

Within the current scientific landscape, the growing climate crisis is inextricably linked to access to fresh, potable water. In this respect the need for improved water management and sanitation are key pillars in mitigating the severe risk to numerous communities that is associated with water scarcity. Indeed, access to clean water is a United Nations Sustainable Development Goal with an estimated 3.6 billion people worldwide now living in areas that are potentially water-scarce, with this estimated to increase to 5.7 billion by $2050,{ }^{10}$ creating strong competition amongst users. Therefore, it is essential that water sanitation, hygiene infrastructure and services are adapted to ensure sustainability and resilience in the face of climate-related risks, this is of utmost importance in communities that have no or limited access to traditional means of water decontamination. The need for alternative solutions to the growing challenges associated with provision of potable water in an ever-urbanizing world threatened by climate change has been noted recently, ${ }^{11,12}$ and there is a particular focus on decentralized approaches to water disinfection.

Access to clean water is a major global priority. Water decontamination is currently achieved by oxidative processes such as chlorination, UV irradiation and ozonation. ${ }^{13}$ Disinfection by-products following chlorination have, however, been linked to carcinogenic effects. ${ }^{14}$ The electrolysis of $(\mathrm{NaCl}$ containing) wastewater is often used to achieve microbicidal activity via the formation of hypochlorous acid species $(\mathrm{HOCl})$ and reactive oxygen species $\left((\mathrm{ROS})[\bullet \mathrm{OH}],\left[\mathrm{H}_{2} \mathrm{O}_{2}\right],\left[\mathrm{O}_{3}\right],\left(\left[\bullet \mathrm{O}_{2}{ }^{-}\right]\right) .{ }^{15}\right.$ However, a major aim is to provide water that is free from toxic chemical residues and consequently growing attention has been placed on $\mathrm{H}_{2} \mathrm{O}_{2} .{ }^{16-18}$ Indeed, with a broad spectrum bactericidal activity (D-value, the value taken to reduce microbial population, is less than $4 \mathrm{~min}$ at $3 \mathrm{wt} . \%)^{19}$ and water being the only by-product from its utilisation, effectively negating the need for dechlorination of toxic residues 
downstream, ${ }^{20} \mathrm{H}_{2} \mathrm{O}_{2}$ can be considered an attractive alternative to traditional biocides. ${ }^{19}$ However, a low sporicidal activity has thus far limited use for sterilization processes. ${ }^{21,22}$

Practically, concentrated pre-formed $\mathrm{H}_{2} \mathrm{O}_{2}$ is used, requiring transport and storage at the point of use. As such, the use of stabilizers to prevent $\mathrm{H}_{2} \mathrm{O}_{2}$ degradation is common, although these deleteriously affect the microbicidal efficacy of $\mathrm{H}_{2} \mathrm{O}_{2}$, with the accumulation of chemical residues also a concern. . $^{23,24}$ The bactericidal activity of $\mathrm{H}_{2} \mathrm{O}_{2}$ is generally thought to occur through the production of hydroxyl radicals ( $\left.\mathrm{HO}^{\circ}\right)$ although the species responsible for the oxidative damage is still disputed. While there is little evidence in the literature to support the primary role of $\mathrm{HOO} / \mathrm{O}_{2}{ }^{-}$species in bacterial remediation, it is reasonable to consider their potential involvement in bacterial kill. ${ }^{20}$ The use of Fenton reactions and the rapid production of oxidative radicals are particularly applicable for water treatments. ${ }^{25}$ However, pre-formed $\mathrm{H}_{2} \mathrm{O}_{2}$ is less effective than chlorination and this limits its application in large-scale water treatment. ${ }^{20}$ The direct synthesis of $\mathrm{H}_{2} \mathrm{O}_{2}$ from $\mathrm{H}_{2}$ and $\mathrm{O}_{2}$ using AuPd nanoparticles has been demonstrated at the laboratory scale as an alternative to the anthraquinone process and would allow for decentralised $\mathrm{H}_{2} \mathrm{O}_{2}$ production in remote locations as well as promoting a localised, circular water economy in more urbanised regions. This would remove the need to store concentrated solutions and provide a route to in situ production of reactive oxygen species with microbicidal activity. ${ }^{4,26,27}$

Within this study we demonstrate that the addition of Au to a Pd catalyst is key in promoting the release of oxygen based radical species, formed during the direct synthesis of $\mathrm{H}_{2}$ and $\mathrm{O}_{2}$, into solution. These species are found to offer bactericidal and virucidal efficacy far greater than that observed via chlorination or through the use of preformed $\mathrm{H}_{2} \mathrm{O}_{2}$ alone while also inhibiting the formation of biofilms, a known cause of pathogen survival and propagation. This approach offers the potential for in situ water purification that can, we propose, be suitable for decentralised applications.

\section{Results}

\section{$\mathrm{H}_{2} \mathrm{O}_{2}$ formation and and radical species identification.}

Given that underlying geology and local environment can result in appreciable variation in the degree of water quality, including hardness and the concentration of inorganic salt impurities, we initially set out to determine the effect of a range of common ions on catalytic activity towards $\mathrm{H}_{2} \mathrm{O}_{2}$ synthesis (Supplementary Fig. 1). These studies were undertaken in a batch reactor, utilising a well-studied AuPd catalyst, ${ }^{5}$ where under extended contact time the possible influence of common ions could be more easily discerned. We found that the addition of common ions such as $\mathrm{Na}^{+}, \mathrm{Ca}^{2+}, \mathrm{Mg}^{2+}, \mathrm{Fe}^{2+}, \mathrm{CO}_{3}^{2-}$, $\mathrm{NO}_{3}{ }^{-}, \mathrm{PO}_{4}{ }^{3-}$ and $\mathrm{SO}_{4}{ }^{2-}$ had no significant effect on $\mathrm{H}_{2} \mathrm{O}_{2}$ synthesis activity. Perhaps unsurprisingly, given the ability of halide ions to inhibit $\mathrm{H}_{2} \mathrm{O}_{2}$ degradation pathways, ${ }^{28}$ the presence of $\mathrm{Cl}^{-}$resulted in an appreciable increase in net $\mathrm{H}_{2} \mathrm{O}_{2}$ concentration (Supplementary Fig. 2-9). Additional studies also established the limited deleterious effect of model organic species; 2-methylisoborneol, geosmin and glucose, with the former two compounds in particular a challenge in water remediation (Supplementary 
Fig. 10-12). With the insignificant effect of model inorganic and organic contaminants established all further work was conducted using HPLC grade water as received, in keeping with standard testing protocols. $^{29}$

We have previously reported that a $1 \% \mathrm{AuPd} / \mathrm{TiO}_{2}$ catalyst can produce $200-1000 \mathrm{ppm}$ of $\mathrm{H}_{2} \mathrm{O}_{2}$ at liquid residence times of approximately 30 seconds, under reaction conditions favourable for water purification. ${ }^{30}$ We now demonstrate, in a similar flow regime (Supplementary Fig. 13), it is possible to synthesise $\mathrm{H}_{2} \mathrm{O}_{2}$ in water over a range of $\mathrm{Au}$ : Pd ratios utilising gas compositions which could be generated through the electrolysis of water and dilution with air. In keeping with previous studies ${ }^{5}$ a synergistic effect between $\mathrm{Au}$ and Pd was observed (Supplementary Fig. 14) and a continuous production of $\mathrm{H}_{2} \mathrm{O}_{2}(200+\mathrm{ppm})$ over the $0.5 \% \mathrm{Au}-0.5 \% \mathrm{Pd} / \mathrm{TiO}_{2}$ catalyst demonstrated (Supplementary Fig. 15). As with our previous investigations, ${ }^{5}$ analysis of post-reaction solutions by inductively coupled plasma atomic emission spectroscopy (ICP-AES) indicates no leaching of precious metal species up to six hours on-stream (Supplementary Table 1).

The direct synthesis of $\mathrm{H}_{2} \mathrm{O}_{2}$ on Pd clusters has been proposed to follow a non-Langmuirian mechanism with a zero-order kinetics with respect to $\mathrm{O}_{2}$ and first order kinetics with respect to $\mathrm{H}_{2}$, at partial pressures similar to our reaction conditions. ${ }^{8}$ Therefore, the catalyst surface sites would likely be saturated with $\mathrm{O}_{2}$-derived intermediates, due to a large heat of adsorption of $\mathrm{O}_{2}$ on water saturated $\mathrm{Pd}$ surfaces, $\left(48-75 \mathrm{~kJ} \mathrm{~mol}^{-1}\right){ }^{31}$ The formation of $\mathrm{H}_{2} \mathrm{O}_{2}$ is considered as a sequential proton - electron transfer events to $\mathrm{O}_{2}$ and $\mathrm{HOO}$ where the chemical potential of $\mathrm{H}_{2}$ oxidation is the thermodynamic driving force.

Figure 1a (i-v) show spin trapping EPR experiments using 5,5-dimethyl-1-pyrroline N-oxide (DMPO) and various gas atmospheres (see Supplementary Note 1). Using $5 \% \mathrm{H}_{2} / \mathrm{N}_{2}$ flow (absence of $\mathrm{O}_{2}$-derived intermediates) we observed the trapping of $\mathrm{H}^{*}$ in the reaction solution proving homolytic $\mathrm{H}_{2}$ cleavage occurs on the catalyst surface and radical diffusion into the surrounding solution (Fig. 1a (i)). Furthermore, when $\mathrm{H}_{2}$ and $\mathrm{H}_{2} \mathrm{O}_{2}$ are fed into the reactor, no radical ROS were detected and only $\mathrm{H}^{*}$ was observed (Fig. 1a(ii)), suggesting that $\mathrm{H}_{2}$ cleavage is not initiating the production of O-centred radicals from $\mathrm{H}_{2} \mathrm{O}_{2}$. The radicals in solution during $\mathrm{H}_{2} \mathrm{O}_{2}$ synthesis over supported AuPd catalysts have not previously been reported. It is reasonable to suggest that any $\mathrm{H}_{2}$ activation would lead to reaction with adsorbed $\mathrm{O}_{2}$ species when both reaction gases are present. Indeed, no signal associated with $\mathrm{H}^{\bullet}$ in solution was detected if both $\mathrm{H}_{2}$ and $\mathrm{O}_{2}$ were used (Fig. 1a (iii)). When $\mathrm{H}_{2} \mathrm{O}_{2}$, commercial or synthesised, is fed through the reactor limited radical ROS are detected under a pressure of $10 \mathrm{bar}$, consistent with the limited biocidal activity observed when $\mathrm{H}_{2} \mathrm{O}_{2}$ is used as a disinfectant (Fig. 1a (ivv)). The EPR spin trapping experiments show that, as previously suggested by Li et al., ${ }^{9}$ surface bound intermediates can desorb from the catalyst surface as radicals in the case of reaction with $\mathrm{H}_{2}$ and $\mathrm{O}_{2}$, and $\mathrm{H}_{2} \mathrm{O}_{2}$ passing through the catalyst bed but not in the case of $\mathrm{H}_{2}$ and preformed $\mathrm{H}_{2} \mathrm{O}_{2}$. When $\mathrm{H}_{2} \mathrm{O}_{2}$ is 
synthesised in situ, this will enrich the aqueous solution of newly formed $\mathrm{H}_{2} \mathrm{O}_{2}$ with a broadband of Ocentred radicals available to attack bacterial cells: highly oxidative, short lived and short range HO' plus longer-range $\mathrm{HOO}^{\prime} / \mathrm{O}_{2}{ }^{-}$(Fig. 1a(iii)). Double integration from spin trapping EPR in conjunction with the calibration curve (Supplementary Figs. 16 and 17) suggested a concentration of trapped O-centred radicals (in the form of DMPO-OH adduct) equal to $0.66 \pm 0.04 \mu \mathrm{M}$, although it is important to note that we are unable to determine concentration of individual oxygen-based radical species. When feeding ex situ synthesised $\mathrm{H}_{2} \mathrm{O}_{2}$, with or without stabilisers at $200 \mathrm{ppm}$, the amount of trapped Ocentred radicals was quantified between $0.13 \pm 0.04 \mu \mathrm{M}$ and $0.18 \pm 0.04 \mu \mathrm{M}$ corresponding to $22-27$ $\%$ of the amount measured when feeding the reactor with $\mathrm{H}_{2}$ and $\mathrm{O}_{2}$. It is important to stress that these concentrations are not the total amount of O-centred radicals released into solution by the Au-Pd catalyst. They are only representative of the amount of radicals trapped in the form of the DMPO-OH adduct at the time of measurements (and before the adduct further reacts via side-reactions). Nevertheless, the changes in relative concentrations of the DMPO-OH adduct do follow the changes of total O-centred radicals released by the catalyst. Concentrations in the range of 0.13 to $0.66 \mu \mathrm{M}$ appear to be much smaller than the concentration of DMPO spin trap added to the water feeding the reactor $(8.8 \mathrm{mM})$. Furthermore, when using a $5 \% \mathrm{H}_{2} / \mathrm{N}_{2}$ gas feed, resulting in the absence of $\mathrm{O}_{2}$-derived intermediates, the concentration of trapped $\mathrm{H}^{\cdot}$ was $7.8 \pm 0.5 \mu \mathrm{M}$ (based on the calibration in Supplementary Figs. 16 and 17) which, although still much smaller than the concentration of spin trap used, is an order of magnitude larger than the concentration of trapped $\mathrm{HO}^{*}$ and $\mathrm{HOO}$. These would suggest that most of the proton-mediated electron transfer events leading to the formation of $\mathrm{H}_{2} \mathrm{O}_{2}$ are indeed surface reactions with $\mathrm{H}_{2} \mathrm{O}_{2}$ being the main product being desorbed from the catalyst surface. However, the AuPd catalysts are also capable of injecting into solution O-based radicals (HO $/ \mathrm{HOO} /$ $\mathrm{O}_{2}{ }^{--}$) which can directly attack bacteria as well as sustain further radical formation through reaction with synthesised $\mathrm{H}_{2} \mathrm{O}_{2}$.

Interestingly, no free radical injection into solution is observed with Pd only catalysts (Fig. 1b(viii-ix)), despite forming $\mathrm{H}_{2} \mathrm{O}_{2}$. However, a detectable amount of radical ROS is observed with Au only catalysts (Fig. 1b(xi)). This observation would indicate that the presence of Au is necessary for desorbing reactive species from the catalyst surface in the form of free radicals. The knowledge generated by these spin trapping EPR experiments prompts the possibility that the radical ROS released into solution, in conjunction with $\mathrm{H}_{2} \mathrm{O}_{2}$, can have applications in water disinfection and this is what we wish to explore in this study.

Concentrations of $\mathrm{H}_{2} \mathrm{O}_{2}$ as low as $125 \mathrm{ppm}$ have been shown to have significant effects on reducing faecal coliform levels in greywater at extended contact times with a similar efficacy to $5 \mathrm{ppm}^{2}$ when treating samples with 90 colony forming units (CFU) per $100 \mathrm{~mL}$. $^{32}$ The catalytic in situ production of ROS to disinfect contaminated water streams would be an attractive development and would also negate health concerns associated with stabilizing agents typically used to promote the shelf-life of commercial 
$\mathrm{H}_{2} \mathrm{O}_{2}{ }^{33,34}$ We now demonstrate that this is indeed a feasible approach to water remediation. In keeping with standard testing protocols, bactericidal efficacy was established in the absence of alternative contaminants which may reduce radical concentrations. ${ }^{29}$ Using these standardised preformed $\mathrm{H}_{2} \mathrm{O}_{2}$, produced either commercially or catalytically (100-200 ppm), exhibited limited bactericidal activity against Escherichia coli K12 JM109 (1.5 $\log _{10}$ reduction within $60 \mathrm{~min}$ ) (Fig. 2a, Supplementary Fig. 18, Supplementary Table 2). To assess the viability of non-catalytic disinfection regimes an active chlorine solution $(\mathrm{NaOCl})$ was added to the flow reactor feed in the absence of catalyst (Fig. $2 \mathrm{~b}$, Supplementary Table 2). Under flow conditions, high (1000 ppm) and low (5 ppm) chlorine concentrations failed to produce significant reduction in Escherichia coli levels $\left(0.37 \log _{10}\right.$ and 0.44 $\log _{10}$ respectively). The lack of bactericidal activity at low residence time in the reactor is consistent with chlorine derived disinfectants being highly effective only over extended contact times at low concentrations $(0.5 \mathrm{ppm}){ }^{35}$ Indeed, the $\mathrm{D}$ value of $\mathrm{NaOCl}$ against Escherichia coli is sufficiently high at the $\mathrm{Cl}$-concentrations used in this work $(6.1 \mathrm{~min}$ at $500 \mathrm{ppm})$, suggesting that chlorine-based disinfection is insufficient for the rapid killing of high concentrations of Escherichia coli and that longer contact times are a prerequisite for adequate disinfection. ${ }^{35}$ Indeed, this in turn can be related to the varying oxidative activity of Cl-based species (hypochlorite, hypochlorous acid), with speciation largely dictated by $\mathrm{pH}$, indeed this dependence a considerable drawback in the use of Cl-based disinfectants. ${ }^{36}$ A comparable limited activity is observed when utilising commercial $\mathrm{H}_{2} \mathrm{O}_{2}$ at a range of concentrations (5-1000 ppm) (Supplementary Table 2). These results show that dilute $\mathrm{H}_{2} \mathrm{O}_{2}$ requires extended times for effective pathogen reduction and for this reason concentrated $\mathrm{H}_{2} \mathrm{O}_{2}(12,000 \mathrm{ppm}$, $1.2 \mathrm{wt} . \%$ ) is typically used, for the remediation of bacteria, such as Escherichia coli, from water. ${ }^{37}$

The reduction in Escherichia coli achieved using the flow reactor system under various gas atmospheres is shown in Fig. $2 \mathrm{c}$ with and without the AuPd based catalyst (30 s liquid residence time). A significantly higher $\left(10^{8} \mathrm{CFU} / \mathrm{mL}\right)$ bacterial concentration than that reported by Ronen et al. was used to perform control experiments. ${ }^{32}$ With no catalyst present, at typical reaction conditions, bacterial concentration decreased by $<1 \log _{10}$ showing that elevated (10 bar) pressure has limited antimicrobial activity. Reactions in the presence of the $0.5 \% \mathrm{Au}-0.5 \% \mathrm{Pd} / \mathrm{TiO}_{2}$ catalyst and $5 \% \mathrm{H}_{2} / \mathrm{N}_{2}$ showed a $0.1 \log 10$ reduction can be explained through the presence of residual $\mathrm{O}_{2}$ in the bacterial solution and low level $\mathrm{H}_{2} \mathrm{O}_{2}$ formation, the analogous reaction in the presence of air resulted in a $0.5 \log _{10}$ reduction indicating limited oxidative damage initiated by the catalyst in the absence of $\mathrm{H}_{2}$ under our reaction conditions. In the presence of a $2 \% \mathrm{H}_{2} /$ air mixture and AuPd catalyst an $8.1 \log _{10}$ reduction in viable bacteria was observed representing a $99.999999 \%$ reduction in CFU with a 30 s contact time through the packed bed. This is comparable to the bactericidal efficacy reported for a range of alternative approaches, including photocatalytic and photo-Fenton technologies (Supplementary Table 3). ${ }^{38,39}$ However, these routes typically require extended reaction times ${ }^{40}$ (on the order of hours) or require the presence of a secondary disinfectant such as $\mathrm{ClO}_{2}{ }^{41}$ or preformed $\mathrm{H}_{2} \mathrm{O}_{2},{ }^{42}$ with the latter generating radical species, 
responsible for disinfection. While these routes are effective, they do not overcome the health concerns associated with the application of Cl-based disinfectants or preformed $\mathrm{H}_{2} \mathrm{O}_{2}$ and the need for continual illumination of the catalyst surface likely precludes this approach from widescale application. By comparison, the rapid generation of ROS from in situ generated $\mathrm{H}_{2} \mathrm{O}_{2}$ is far simpler and would not require significant redesign of reactor technology.

The bactericidal activity of our in situ approach is observed to be significantly higher than suspension tests at similar $\mathrm{H}_{2} \mathrm{O}_{2}$ concentrations at short (1 $\mathrm{min}$ ) and long (60 min) exposure times and significantly higher than that observed when either commercial or catalytically synthesised $\mathrm{H}_{2} \mathrm{O}_{2}$ are passed through the catalyst with the bacteria solution at identical contact times. With these observations suggesting different processes are occurring during the reaction between $\mathrm{H}_{2}$ and $\mathrm{O}_{2}$ which lead to the rapid bactericidal efficacy observed (Fig. 2a). The $\mathrm{H}_{2} \mathrm{O}_{2}$ present in reactor effluent with and without Escherichia coli was comparable, indicating that the biocidal activity is independent from the generation or consumption of $\mathrm{H}_{2} \mathrm{O}_{2}$ by the catalyst (Supplementary Fig. 19). With the concentration of residual $\mathrm{H}_{2} \mathrm{O}_{2}$ comparable to the allowable limits of $\mathrm{H}_{2} \mathrm{O}_{2}$ within drinking water recommended by the US Environmental Protection Agency ${ }^{43}$ the ability of low levels of residual $\mathrm{H}_{2} \mathrm{O}_{2}$ to prolong the potable lifetime of the treated water should also be considered.

MS2 is a safe surrogate for the poliovirus and other small non-enveloped pathogenic viruses due to its comparable size and response to virucides. ${ }^{44}$ Using the same test conditions an $8.0 \log _{10}$ reduction in viability of the non-enveloped virus MS2 was observed when passed over the AuPd catalyst in conjunction with $\mathrm{H}_{2}$ and $\mathrm{O}_{2}$ (Fig 2.d). Again, this contrasts with the complete lack of virucidal activity observed when using $200 \mathrm{ppm}$ of commercial or synthesised $\mathrm{H}_{2} \mathrm{O}_{2}$ (Fig. 2d) in suspension tests suggesting that the active agent formed under flow conditions is not likely to be $\mathrm{H}_{2} \mathrm{O}_{2}$.

Microbial biofilms pose another significant challenge in water decontamination and are less susceptible to standard disinfection treatments. As such residual $\mathrm{H}_{2} \mathrm{O}_{2}$ could additionally be used to minimise the formation of bacterial biofilms on surfaces downstream of our catalytic system, with $\mathrm{H}_{2} \mathrm{O}_{2}$ well known to disrupt biofilm formation. ${ }^{45}$ Catalytically produced $\mathrm{H}_{2} \mathrm{O}_{2}$ is seen to impact on Escherichia coli $\mathrm{K} 12$ JM109 attachment to surfaces, with 200 of synthesised $\mathrm{H}_{2} \mathrm{O}_{2}$ producing a higher reduction in bacterial biomass compared to an equivalent concentration of commercial $\mathrm{H}_{2} \mathrm{O}_{2}$ (Supplementary Fig. 20), or chlorine up to 2 ppm (Supplementary Fig. 21).

Study of Au: Pd ratio revealed all catalysts offer some bactericidal activity (Fig 3a., Supplementary Fig. 22 ). However, the $0.5 \% \mathrm{Au}-0.5 \% \mathrm{Pd} / \mathrm{TiO}_{2}$ catalyst showed significantly enhanced efficacy $\left(8.1 \log _{10}\right.$ reduction) compared to the $\mathrm{Au}$ - $\left(1.6 \log _{10}\right.$ reduction $)$ or $\mathrm{Pd}$-rich catalysts $\left(4.1 \log _{10}\right.$ reduction) in addition to the monometallic Au and Pd catalysts. This is despite the bi-metallic AuPd and Pd-only catalysts producing similar concentrations of residual $\mathrm{H}_{2} \mathrm{O}_{2}(163-202 \mathrm{ppm})$ and further demonstrates that the enhanced reduction in $\mathrm{CFU}$ observed over the $0.5 \% \mathrm{Au}-0.5 \% \mathrm{Pd} / \mathrm{TiO}_{2}$ catalyst is not simply related to 
$\mathrm{H}_{2} \mathrm{O}_{2}$ production. The corresponding apparent turnover frequencies (TOFs) based on mmol of metal further highlights the stark differences in bactericidal efficacy (Supplementary Table 4), with the

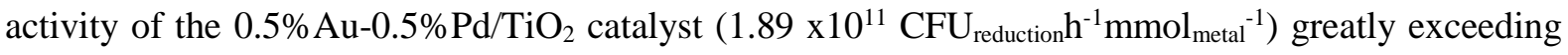
that determined for the alternative formulations.

The extensive reduction in Escherichia coli observed can be associated with fast and extensive loss of membrane function, bacterial homeostasis and the release of intracellular components, driven by $\mathrm{HO}^{*}$ as the primary oxidant species. ${ }^{46}$ Lipids and proteins composing the bacterial membrane have been proven to be vulnerable to reactions with $\mathrm{HO}$ via $\mathrm{H}$ abstraction besides other oxidation pathways. ${ }^{47} \mathrm{At}$ the same time, $\mathrm{O}_{2}{ }^{-}$and $\mathrm{H}_{2} \mathrm{O}_{2}$ are only moderately reactive when compared to $\mathrm{HO}^{\cdot}{ }^{46}$ and, although they have been associated with internal damage, ${ }^{48}$ their action would be a much lengthier process regulated by diffusion and mass transport through the membrane and within the cytoplasmatic medium. In addition Escherichia coli expresses the enzymes superoxide dismutase (SOD) and catalase, which are devoted to inhibiting damage from $\mathrm{O}_{2}{ }^{-}$and $\mathrm{H}_{2} \mathrm{O}_{2}$ respectively, but there is no enzymatic mechanism to eliminate $\mathrm{HO}^{*}{ }^{49}$ These factors as well as the reaction kinetics of O-centred radicals in solution, (see Supplementary Note 1) which show that conversion of $\mathrm{HOO}^{*} / \mathrm{O}_{2}{ }^{--}$into $\mathrm{HO}^{*}$ cannot happen; indicate that the high bactericidal efficacy observed is largely driven by $\mathrm{HO}^{*}$ directly formed over the catalyst. Although more work needs to be done to further understand speciation of the radicals in solution and their direct vs. indirect effect on bacterial deactivation, it is clear that the linear correlation existing between total radical ROS concentration and log kill (Fig 3b), confirms the enhanced bactericidal effect of using $\mathrm{H}_{2}$ and $\mathrm{O}_{2}$ when compared to preformed $\mathrm{H}_{2} \mathrm{O}_{2}$. This is further corroborated by the near total reduction in bactericidal activity in the presence of glutathione $(5 \mathrm{mM})$, a quencher of $\mathrm{HO}$ (Fig. $3 \mathrm{c}),{ }^{50}$ with bactericidal activity decreasing to levels equivalent to that observed when using preformed $\mathrm{H}_{2} \mathrm{O}_{2}$ (Fig 2c).

To achieve a high killing efficacy, bacteria have to pass through the catalyst bed in the presence of $\mathrm{H}_{2}$ and $\mathrm{O}_{2}$ as placing the bacterial suspension after the bed, to ensure immediate exposure to the synthesised $\mathrm{H}_{2} \mathrm{O}_{2}$, resulted in no significant reduction in CFU (Fig. 3c). The bactericidal efficacy observed in close proximity to the catalyst bed suggests that reactive species generated over the catalyst are far more effective than the generation of ROS through subsequent $\mathrm{H}_{2} \mathrm{O}_{2}$ decomposition.

\section{Catalyst structure, composition and stability.}

AuPd catalysts prepared via an impregantion procedure and exposed to reductive heat treatments are well known to result in the formation of random alloy metal nanoparticles, with a a tight particle size distribution, typically in the range of 2-5 nm observed. ${ }^{51}$ Analysis of the supported AuPd catalysts by X-ray diffraction (Supplementary Fig. 23) and high-angle annular dark-field scanning transmission electron microscopy (HAADF-STEM) of the as-prepared powdered catalysts are in keeping with these previous observations. A limited amount of particle agglomeration takes place due to the pelleting 
process, with mean particle size increasing from $2.9 \mathrm{~nm}$ in the powdered catalyst to $4.5 \mathrm{~nm}$ in the pelleted analogue (Representative micrographs seen in Fig.4.a, particle size histograms seen Supplementary Fig. 24). Evaluation of atomic surface ratios by X-ray photoelectroon spectrscopy (XPS) (Fig. 4b, Supplementary Table 5) reveals that the introduction of Au significantly modifies Pd-oxidation state, with the proportion of $\mathrm{Pd}^{2+}$ in the optimal $0.5 \% \mathrm{Au}-0.5 \% \mathrm{Pd} / \mathrm{TiO}_{2}$ catalyst greatly increased compared to the Pd-only analogue. While the presence of domains of mixed Pd oxidation state is well known to improve catalytic performance towards $\mathrm{H}_{2} \mathrm{O}_{2}$ production ${ }^{52,53}$ we show that this is not a key factor responsible for enhanced bactericidal efficacy, with all bi-metallic AuPd catalysts observed to contain Pd of mixed oxidation state.

It is clear that our in situ approach is far more effective than equivalent concentrations of preformed, commercial $\mathrm{H}_{2} \mathrm{O}_{2}$. We suggest that $\mathrm{H}^{\cdot}$ are not directly involved in the bactericidal activity under the conditions where a high bacterial kill is observed. Indeed, the low bactericidal activity observed (i.e. $<1$ $\log _{10}$ reduction) under $5 \% \mathrm{H}_{2} / \mathrm{N}_{2}$ alone also confirms that $\mathrm{H}^{*}$ are not involved in the killing of the bacteria. EPR spectra with the addition of $5 \mathrm{mM}$ glutathione (Fig. $1 \mathrm{~b}$ (vi-vii)) demonstrated that under $5 \% \mathrm{H}_{2} / \mathrm{N}_{2}$, $\mathrm{H}^{*}$ could be detected in solution whereas under $\mathrm{H}_{2}$ and $\mathrm{O}_{2}$ mixtures no ROS were detected, supporting the hypothesis that $\mathrm{H}^{*}$ are not responsible for microbicidal activity and that glutathione removed the ROS from solution correlating with the low bactericidal activity.

Whilst we have shown that the $0.5 \% \mathrm{Au}-0.5 \% \mathrm{Pd} / \mathrm{TiO}_{2}$ catalyst is capable of continuous $\mathrm{H}_{2} \mathrm{O}_{2}$ production in a water only solvent for several hours on stream (Supplementary Fig 15), with no observable metal leaching (Supplementary Table 1), it is important to determine catalyst stability with respect to pathogen kill. As such, sequential reactions with increasing starting concentrations of Escherichia coli K12 JM109 were performed over the same catalyst bed. The reactor was flushed with ethanol (70 wt.\% aqueous solution) and deionised water between runs to ensure identical starting conditions and the complete removal of residual Escherichia coli. We observe that bactericidal efficacy is retained when the catalyst is treated in this manner, with complete pathogen kill observed at starting concentrations between $6.3-8.9 \log _{10} \mathrm{CFU} / \mathrm{mL}$ (Fig. 5a). Hence the effects observed are long lived and demonstrates that the catalyst does not deactivate, at least over three uses. To investigate the origin of the enhanced pathogen kill on reuse, we carried out similar EPR experiments with the catalyst that had previously been used for pathogen kill (Fig. 5b) and where the catalyst bed had been treated with ethanol followed by deionised water. Figure $5 \mathrm{~b}$ shows that together with DMPO-OH another adduct is now visible which arises from the trapping of $\mathrm{CH}_{3} \mathrm{C}^{*} \mathrm{HOH}$ radical (see Supplementary Note 2) ${ }^{54}$ The latter is formed from residual ethanol adsorbed on the catalyst after flushing which scavenges $\mathrm{HO}^{*}$ formed by the catalyst. This is in keeping with work by Kiwi and Nadtochenko who have reported the ability of carbon-centred radicals, in this case produced photo-catalytically, to propagate radical production, resulting in oxidative damage of Escherichia coli. ${ }^{55}$ 
Our observation provides further direct proof of the presence of $\mathrm{HO}^{*}$ in solution, as primary aliphatic alcohols are known to undergo $\alpha$-hydrogen abstraction due to the strong electrophilic nature of $\mathrm{HO}^{\bullet 56,57}$ ( $\mathrm{HOO} \% \mathrm{O}_{2}{ }^{--}$and $\mathrm{H}_{2} \mathrm{O}_{2}$ are more specifically scavenged by superoxide dismutase ${ }^{58,59}$ and catalase respectively $\left.{ }^{60}\right)$. In addition, important considerations can be drawn by comparing the reactions using the $\mathrm{H}_{2}$ and $\mathrm{O}_{2}$ gas mixture with preformed $\mathrm{H}_{2} \mathrm{O}_{2}$. First, in line with the case of fresh catalysts, where there was no ethanol pre-treatment, when $\mathrm{H}_{2}$ and $\mathrm{O}_{2}$ was passed through the $0.5 \% \mathrm{Au}-0.5 \% \mathrm{Pd} / \mathrm{TiO} \mathrm{O}_{2}$ catalyst, the total amount of radicals trapped is at least 2.5 times the amount trapped when using 200 ppm of preformed $\mathrm{H}_{2} \mathrm{O}_{2}$ solution in air. As for the carbon-centred radical species deriving from residual ethanol scavenging $\mathrm{HO}^{*}$, the trapped amount when using $\mathrm{H}_{2}$ and $\mathrm{O}_{2}$ is ca. 3.6 times the amount trapped when using preformed $\mathrm{H}_{2} \mathrm{O}_{2}$. This implies that per unit of ROS trapped, when using $\mathrm{H}_{2}$ and $\mathrm{O}_{2}$ there is more $\mathrm{CH}_{3} \mathrm{C}^{*} \mathrm{HOH}$ being trapped than when using preformed $\mathrm{H}_{2} \mathrm{O}_{2}$; specifically DMPO-CH$\left(\mathrm{CH}_{3}\right) \mathrm{OH}$ (ca. $0.28 \mu \mathrm{M}$ ) accounting for $74.5 \%$ of the concentration of DMPO-OH (ca. $0.38 \mu \mathrm{M}$ ) in the case of a $\mathrm{H}_{2}$ and $\mathrm{O}_{2}$ mixture but only $39.8 \%$ in the case of preformed $\mathrm{H}_{2} \mathrm{O}_{2}$. EPR analysis therefore indicates that when using $\mathrm{H}_{2}$ and $\mathrm{O}_{2}$ the relative contribution of $\mathrm{HO}^{*}$ over the total ROS generated is greater than the case of preformed $\mathrm{H}_{2} \mathrm{O}_{2}$. This provides further important evidence to explain the higher bactericidal efficacy observed when using $\mathrm{H}_{2}$ and $\mathrm{O}_{2}$.

We propose the difference in radical flux and hence the dramatically increased bactericidal ability of the $\mathrm{H}_{2}$ and $\mathrm{O}_{2}$ mixtures in the presence of the AuPd catalyst depends on the initiation steps of the radical flux. In the case of $\mathrm{H}_{2}$ and $\mathrm{O}_{2}$, the presence of $\mathrm{H}^{*}$ from homolytic $\mathrm{H}_{2}$ dissociation initiates the reaction cascade by turning adsorbed $\mathrm{O}_{2}$ into $\mathrm{HO}^{*} / \mathrm{HOO}^{*}$ which either irreciprocally damage the bacterial cells or propagate the radical chain with contribution from synthesised $\mathrm{H}_{2} \mathrm{O}_{2}$ to support the radical flux away from the catalyst surface. In the case of preformed $\mathrm{H}_{2} \mathrm{O}_{2}$, the initiation can only occur by cleaving the $\mathrm{O}-\mathrm{O}$ bond which is known to be kinetically slower when compared to $\mathrm{O}-\mathrm{O}$ bond cleavage in $\mathrm{HOO}^{\circ}{ }^{8}$ and therefore the radical flux when using preformed $\mathrm{H}_{2} \mathrm{O}_{2}$ is significantly hindered, as proved by our EPR studies in conjunction with the different reaction times necessary to obtain the same level of cell killing (1 $\min v s .60 \mathrm{~min})$.

Bactericidal activity results combined with EPR data (Fig. 1 and 3) show that a high radical flux in solution is achieved by the bimetallic $0.5 \% \mathrm{Au}-0.5 \% \mathrm{Pd} / \mathrm{TiO}_{2}$ catalyst but not by the monometallic $\mathrm{Au}$ and Pd analogues (Supplementary Fig. 24). As shown, $\mathrm{Pd}$ can catalyse direct formation of $\mathrm{H}_{2} \mathrm{O}_{2}$, however the reactive intermediates of the direct synthesis of $\mathrm{H}_{2} \mathrm{O}_{2}$ remain on the surface ${ }^{61}$ not allowing the generation of the radical flux necessary to achieve high bactericidal efficacy (Fig. 1b(viii-ix)). On the contrary, $\mathrm{Au}$ alone has very low activity towards $\mathrm{H}_{2} \mathrm{O}_{2}$ production, hence the number of radical species that it is able to generate is low. However, Au facilitates the diffusion into solution (from the catalyst surface) of the reactive intermediates of the direct synthesis of $\mathrm{H}_{2} \mathrm{O}_{2}$ in the form of free radicals (Fig. 1b(xi)). As a result, it is clear that Pd is needed for the generation of a high amount of ROS whilst 
Au ensures that they are released into solution where they can be used to kill pathogens, enhancing the disinfection mechanism provided by $\mathrm{H}_{2} \mathrm{O}_{2}$.

\section{Conclusions.}

In the direct synthesis of $\mathrm{H}_{2} \mathrm{O}_{2}$ alloying $\mathrm{Au}$ with $\mathrm{Pd}$ has been widely theorised to result in improved desorption of $\mathrm{H}_{2} \mathrm{O}_{2}$. We now demonstrate that AuPd nanoalloys are also effective in promoting the release of highly reactive oxygen-based radical species into solution, as identified by EPR analysis, which offer high efficacy in water disinfection. We have yet to fully identify whether it is $\bullet \mathrm{OH}, \bullet \mathrm{OOH}$ or a combination that is responsible for the disinfection and this will be a topic for further study and studies under real world conditions are required the significantly enhanced bactericidal and virucidal activities achieved when reacting $\mathrm{H}_{2}$ and $\mathrm{O}_{2}$ rather than using commercial $\mathrm{H}_{2} \mathrm{O}_{2}$ or chlorination shows the potential of revolutionising water disinfection technologies, i.e. a process where, besides the catalyst, inputs of contaminated water and electricity are the only requirements to attain disinfection. Indeed, these observations may prove to be the basis of a technology that allows for rapid disinfection of water at contact times for which conventional biocidal methods are ineffective, whilst also bypassing the formation of hazardous disinfection by-products and inhibiting the formation of biofilms, which are at the core of many pathogens persistence and propagation. In particular, communities where the constant supply of dedicated chemicals for water purification is problematic or where localised water disinfection is preferred may benefit from such an approach to water remediation. 
Figure 1. Identification of key reactive oxygen species responsible for the treatment of greywater pathogens. Experimental (black) and simulated (red) X-band CW-EPR spectra of DMPO radical adducts formed in aqueous solutions passed through the catalyst bed in the flow reactor with different fresh catalysts and different gas feedstocks: (i-vii) $0.5 \% \mathrm{Au}-0.5 \% \mathrm{Pd} / \mathrm{TiO}_{2}$ catalyst, with (i) $10 \mathrm{bar} 5 \% \mathrm{H}_{2} / \mathrm{N}_{2}$; (ii) $200 \mathrm{ppm}$ of synthesised $\mathrm{H}_{2} \mathrm{O}_{2}, 10$ bar $5 \% \mathrm{H}_{2} / \mathrm{N}_{2}$; (iii) 10 bar $2 \% \mathrm{H}_{2} /$ air; (iv) 200 ppm of synthesised $\mathrm{H}_{2} \mathrm{O}_{2}$ solution, 10 bar air; (v) 200 ppm of commercial $\mathrm{H}_{2} \mathrm{O}_{2}, 10$ bar air; (vi) 10 bar $5 \% \mathrm{H}_{2} / \mathrm{N}_{2}+5 \mathrm{mM}$ of glutathione; (vii) 10 bar $2 \% \mathrm{H}_{2} /$ air +5 $\mathrm{mM}$ of glutathione. (viii-ix) $1 \% \mathrm{Pd} / \mathrm{TiO}_{2}$ catalyst, with (viii) 10 bar $5 \% \mathrm{H}_{2} / \mathrm{N}_{2}$; (ix) 10 bar $2 \% \mathrm{H}_{2} /$ air. (x-xi) $1 \%$ $\mathrm{Au} / \mathrm{TiO}_{2}$ catalyst, with (x) 10 bar $5 \% \mathrm{H}_{2} / \mathrm{N}_{2}$; (xi) 10 bar $2 \% \mathrm{H}_{2} /$ air. Spectra (i-xi) were recorded at $25{ }^{\circ} \mathrm{C} ; 5.02$ $10^{4}$ receiver gain; $100 \mathrm{kHz}$ modulation frequency; 1.5 Gauss modulation amplitude; $6.48 \mathrm{~mW}$ microwave power. ${ }^{14} \mathrm{~N}$ and ${ }^{1} \mathrm{H}$ hyperfine couplings are also reported. Note: The presence of DMPO-OH adduct is an indication of the presence of both $\mathrm{HO}^{\circ}$ and $\mathrm{HOO}^{\circ}$, given that the DMPO-OOH adduct has a half-life of 1-4 min (i.e. much shorter than the time passed between sample collection from the reactor and EPR analysis) and decays (given an excess of DMPO) into DMPO-OH. ${ }^{61,62}$

Figure 2. Comparison of microbiocidal efficacy using conventional disinfection agents. (a) Microbicidal activity of $\mathrm{H}_{2} \mathrm{O}_{2}$ solution measured with a standardised suspension test. Statistical relevance: $(n=3)$ error bars represent standard error of the mean. Two-way repeated measures ANOVA with a Bonferroni post hoc test was carried out. $\mathrm{F}=5.08$, degrees of freedom $=3 .^{*}=\mathrm{P} \leq 0.05$ (comparing different concentrations of same $\mathrm{H}_{2} \mathrm{O}_{2}$ source). (b) Reduction in bacterial viability $\left(\log _{10}\right)$ using a co-feed of aqueous $\mathrm{NaOCl}$ under flow conditions. Statistical relevance: $(n=3)$ error bars represent standard error of the mean. (c) Reduction in bacterial viability $\left(\log _{10}\right)$ after a single pass through the reactor system; initial bacterial concentration $2 \times 10^{8} \mathrm{CFU} / \mathrm{mL}$. Statistical relevance: *** significant $(\mathrm{P}<0.0001)$ difference with the blank; *** significant $(\mathrm{P}<0.0001)$ difference with 2 $\% \mathrm{H}_{2} /$ air. $(\mathrm{n}=3)$, error bars represent standard error of the mean. One-way ANOVA with a Bonferroni post hoc test was carried out. $\mathrm{F}=64.04$, degrees of freedom $=9.1$. (d) Virucidal activity after $1 \mathrm{~min}$ contact time suspension test (initial MS2 virus concentration: $5 \times 10^{10}$ plaque forming unit $(\mathrm{PFU}) / \mathrm{mL}$ ) or a single pass through the reactor system Statistical relevance: $(n=3$ for the suspension tests and $n=2$ for the catalytic reactor test), error bars represent standard error of the mean. One-way ANOVA with a Bonferroni post hoc test was carried out. $\mathrm{F}=700.6$, degrees of freedom $=4$. The $* * *=P<0.0001$. Reaction conditions for $\mathbf{2 b}-\mathbf{d}: 10$ bar $2 \% \mathrm{H}_{2}, 20 \% \mathrm{O}_{2}, 78 \% \mathrm{~N}_{2}$, $42 \mathrm{~mL} \mathrm{~min}^{-1}$ ), $120 \mathrm{mg}$ catalyst, $0.2 \mathrm{~mL} \mathrm{~min}{ }^{-1}$ liquid flow, $2^{\circ} \mathrm{C}$. 
Figure 3. Catalyst performance and correlation between reactive oxygen species concentration and bactericidal efficacy. (a) Observed steady state $\mathrm{H}_{2} \mathrm{O}_{2}$ production and bactericidal activity against E. coli $\mathrm{K} 12$ JM109 (D) of $1 \% \mathrm{AuPd} / \mathrm{TiO}_{2}$ catalysts, as a function of $\mathrm{Au}$ : Pd ratio, at conditions relevant for water treatment. Statistical relevance: $(n=3)$ error bars represent standard deviation of the mean. (b) Correlation analysis between reduction in bacterial viability $\left(\log _{10}\right)$ after a single pass through the reactor system and relative (to commercial $\mathrm{H}_{2} \mathrm{O}_{2}$ and air with fresh $0.5 \% \mathrm{Au}-0.5 \% \mathrm{Pd} / \mathrm{TiO}_{2}$ ) amount of ROS radicals; the shaded area represents the $90 \%$ confidence band. Data points are relative to the EPR spectra where either $\mathrm{H}_{2}$ and air or $\mathrm{H}_{2} \mathrm{O}_{2}$ and air mixtures were used. (c) Bactericidal activity of $0.5 \% \mathrm{Au}-0.5 \% \mathrm{Pd} / \mathrm{TiO}_{2}$ under full reaction conditions, by placing the bacteria after the catalyst bed under reaction conditions and in the presence of $5 \mathrm{mM}$ glutathione. Statistical relevance: $(n=3)$ error bars represent standard deviation of the mean. Reaction conditions for $3 \mathbf{a}$ and $\mathbf{b}: 10$ bar, $2 \% \mathrm{H}_{2} /$ air, $42 \mathrm{mLmin}^{-1}, 120 \mathrm{mg}$ catalyst, $0.2 \mathrm{~mL} \mathrm{~min}^{-1}$ liquid flow, $2{ }^{\circ} \mathrm{C}$.

Figure 4. AuPd catalyst structure and morphology. (a) Representative STEM-HAADF images of selected catalysts: (i) As prepared powdered $0.5 \% \mathrm{Au}-0.5 \% \mathrm{Pd} / \mathrm{TiO}_{2}$ catalyst; (ii) Pelleted $0.5 \% \mathrm{Au}-0.5 \% \mathrm{Pd} / \mathrm{TiO}_{2}$ catalyst; (iii) Pelleted $1 \% \mathrm{Au} / \mathrm{TiO}_{2}$ catalyst; (iv) Pelleted $1 \% \mathrm{Pd} / \mathrm{TiO}_{2}$ catalyst. (b) Surface atomic compositions of powdered (red) and pelleted (green) catalysts as determined by XPS using Au (4f) and Pd (3d) regions.

Figure 5. Catalytic stability over increasing concentrations of bacteria. (a) Reduction in bacterial viability of E. coli $\mathrm{K} 12 \mathrm{JM} 109$ after a single pass through the reactor system with used $0.5 \% \mathrm{Au}-0.5 \% \mathrm{Pd} / \mathrm{TiO}_{2}$ catalyst and increasing bacterial starting concentration. Red bar shows the starting concentration and the black square the concentration exiting the catalyst bed. Reactor system and catalyst bed flushed with $\mathrm{EtOH}$ and deionized water between subsequent runs. Reaction conditions for $5 \mathrm{a}$ : $10 \mathrm{bar}$, $5 \% \mathrm{H}_{2} / \mathrm{CO}_{2}+25 \% \mathrm{O}_{2} / \mathrm{CO}_{2}\left(42 \mathrm{~mL} \mathrm{~min}^{-1}\right), 0.2 \mathrm{~mL}$ $\mathrm{min}^{-1}$ liquid flow, $2{ }^{\circ} \mathrm{C}, 120 \mathrm{mg} 1 \% \mathrm{AuPd} / \mathrm{TiO}_{2}$ catalyst. (b) Experimental (black) and simulated (red) X-band CW-EPR spectra of DMPO radical adducts formed in aqueous solutions passed over the $0.5 \% \mathrm{Au}-0.5 \% \mathrm{Pd} / \mathrm{TiO}_{2}$ catalyst previously used with different gas feedstocks: (i) $10 \mathrm{bar}, 5 \% \mathrm{H}_{2} / \mathrm{CO}_{2}+25 \% \mathrm{O}_{2} / \mathrm{CO}_{2}$ and (ii) $200 \mathrm{ppm}$ of synthesised $\mathrm{H}_{2} \mathrm{O}_{2}$ solution, 10 bar air. Spectra were recorded at $25^{\circ} \mathrm{C} ; 1.0010^{4}$ receiver gain; $100 \mathrm{kHz}$ modulation frequency; 1.0 Gauss modulation amplitude; $6.22 \mathrm{~mW}$ microwave power. ${ }^{14} \mathrm{~N}$ and ${ }^{1} \mathrm{H}$ hyperfine couplings are also reported. For spectrum (ii) a magnification of a portion of the spectrum is also provided, given the lower signal amplitude when compared to spectrum (i). 


\section{Methods.}

\section{Catalyst preparation.}

Bimetallic 1\%AuPd catalysts were synthesised by co-impregnating the appropriate catalyst support with a requisite amount of $\mathrm{Au}$ and $\mathrm{Pd}$ precursor solutions to give the desired total weight loading of 1 wt. $\%$ with variable metal weight ratios. The preparation of $2 \mathrm{~g}$ of a typical $0.5 \% \mathrm{Au}-0.5 \% \mathrm{Pd} / \mathrm{TiO}_{2}$ catalyst follows the procedure which has been previously reported in the literature. ${ }^{63} \mathrm{~A}$ Pd precursor solution was prepared by dissolving $\mathrm{PdCl}_{2}\left(6 \mathrm{mg} \mathrm{mL}^{-1}, 99.9 \%\right.$, Sigma Aldrich) into a $0.58 \mathrm{M} \mathrm{HCl}$ solution and stirred until the salt was fully dissolved. Requisite amounts of $\mathrm{HAuCl}_{4}\left(12.25 \mathrm{mg} \mathrm{mL}^{-1}\right.$, $99 \%>$ trace metal basis, Strem Chemicals) and $\mathrm{PdCl}_{2}$ were charged into a $50 \mathrm{~mL}$ round bottom flask and stirred vigorously (1000 rpm). The volume of the mixture was adjusted by addition of $\mathrm{H}_{2} \mathrm{O}$ (HPLC grade) until the total volume was $16 \mathrm{~mL}$. The mixture was heated from room temperature to $60{ }^{\circ} \mathrm{C}$ and after 10 minutes of heating the $\mathrm{TiO}_{2}$ support (1.98 g, Degussa, $\left.\mathrm{P} 25,99.5 \%\right)$ was slowly added. Once all the support had been added the resultant slurry was stirred at $60^{\circ} \mathrm{C}$ for 30 minutes, the temperature was then raised to $95{ }^{\circ} \mathrm{C}$ and the slurry was heated for $16 \mathrm{~h}$. The resulting powder was finely ground and finally reduced $\left(5 \% \mathrm{H}_{2} / \mathrm{Ar}\right.$, 4 hours, $\left.400{ }^{\circ} \mathrm{C}, 10{ }^{\circ} \mathrm{C} \mathrm{min}^{-1}\right)$. A similar impregnation methodology which has been previously reported in the literature ${ }^{63}$ using requisite amounts of $\mathrm{HAuCl}_{4}$ and non-acidified $\mathrm{PdCl}_{2}$ solution was utilised for the preparation of the $2.5 \% \mathrm{Au}-2.5 \% \mathrm{Pd} / \mathrm{TiO}_{2}$ catalyst. The as prepared ground powdered catalyst was calcined (static air, 3 hours, $400{ }^{\circ} \mathrm{C}, 10^{\circ} \mathrm{C} \mathrm{min}{ }^{-1}$ ) prior to testing.

\section{Catalytic testing.}

A continuous fixed bed rector was constructed for the direct synthesis of $\mathrm{H}_{2} \mathrm{O}_{2}$ using Swagelok fittings and 316 stainless steel tubing with an outer diameter of 1/8 inch. Gas flows were controlled using mass flow controllers (MFCs) and one-way valves were placed after the MFCs to prevent any liquid from entering the MFCs during the reaction. Reactor pressure was maintained using a back-pressure regulator at the end of the system and pressure relief valves were included at various points throughout the system. Solvent was pumped through the system using an HPLC pump. Liquid was collected downstream of the catalyst bed by emptying a $150 \mathrm{~mL}$ GLS fitted with a valve which acted as a sample bomb.

A typical $\mathrm{H}_{2} \mathrm{O}_{2}$ synthesis reaction was carried out using $120 \mathrm{mg}$ of $1 \% \mathrm{AuPd} / \mathrm{TiO}_{2}$ which had been pressed $(10 \mathrm{~T}, 30 \mathrm{~s})$ into a disk and sieved to a particle size of $425-250 \mu \mathrm{m}$. The granulated catalyst was mixed with silicon carbide powder, sieved to 350-200 $\mu \mathrm{m}$ particle size and supported at the bottom of the catalyst bed in the reactor tube by glass wool. The catalyst and diluent was contained within a 10 $\mathrm{cm}$ stainless steel tube with an outer diameter of $1 / 4$ inch. The reactor system was then pressurised, typically to 10 bar. The reactor was then cooled by the water bath to $2{ }^{\circ} \mathrm{C}$. When the reactor had reached pressure and the flow through the system has stabilised, the solvent $\left(\mathrm{H}_{2} \mathrm{O}, \mathrm{HPLC}\right.$ grade $)$ flow, typically $0.2 \mathrm{~mL} \mathrm{~min}^{-1}$, was introduced into the system. Both gas and liquid flowed concurrently through the 
catalyst bed from top to bottom. $\mathrm{H}_{2} \mathrm{O}_{2}$ was determined by titration against an acidified dilute $\mathrm{Ce}\left(\mathrm{SO}_{4}\right)$ solution using ferroin as an indicator.

The standard reaction conditions for the bacterial testing were: 10 bar pressure, $2{ }^{\circ} \mathrm{C}, 42 \mathrm{mLmin}^{-1}$ gas flow of $2 \% \mathrm{H}_{2} /$ air (unless otherwise stated), suspension flow rate $=0.2 \mathrm{mLmin}^{-1}, 120 \mathrm{mg}$ of $1 \% \mathrm{AuPd} / \mathrm{TiO}_{2}$ catalyst, $3.2 \mathrm{~g} \mathrm{SiC}$. The sample was taken after $30 \mathrm{~min}$ of reaction and E. coli $\mathrm{K} 12 \mathrm{JM} 109$ was plated on a Tryptone Soy Agar plate in duplicates and incubated overnight in $37^{\circ} \mathrm{C}$ in aerobic conditions. MS-2 bacteriophages were enumerated by mixing the bacteriophages with E. coli NCIMB 9481 in a 1:1 ratio in $5 \mathrm{~mL}$ of $65 \%$ Tryptone Soy Agar with $5 \mathrm{mM} \mathrm{CaCl}_{2}$ in duplicates, dispensing the mixture onto Tryptone Soy Agar plates and incubating them overnight at $37{ }^{\circ} \mathrm{C}$ in an aerobic atmosphere.

The efficacy of chlorine disinfection under flow conditions was determined using a modified protocol. In this case, a second HPLC pump was used to feed stock solutions of $\mathrm{NaOCl}$ into the reactor downstream from the mixing of the bacterial suspension and gas phase. The gas-liquid separator was also charged with a solution of sodium thiosulfate to neutralise the chlorine species and prevent further bacterial deactivation after flow through the reactor. For example, in testing the efficacy of $200 \mathrm{ppm}$ of $\mathrm{Cl}_{2}$ under flow conditions, a $3370 \mathrm{ppm} \mathrm{NaOCl}$ (2000 ppm available chlorine equivalent) solution was introduced at $0.02 \mathrm{~mL} \mathrm{~min}^{-1}$ into a stream of air and bacterial suspension, flow rates $42 \mathrm{~mL} \mathrm{~min}^{-1}$ and $0.18 \mathrm{~mL} \mathrm{~min}^{-1}$ respectively, achieving an active chlorine concentration of $200 \mathrm{ppm}$. The gas-liquid separator was charged before reaction with sodium thiosulfate solution (1 mL, $2700 \mathrm{ppm})$, and the sample taken after 30 min of reaction.

The flow regime commonly seen in channels with diameters in the order of the reactor used in this study is called Taylor flow, ${ }^{61}$ which was confirmed by a series of visualisation experiments. The flow was observed to consist of an alternating sequence of gas bubbles and liquid slugs where the length of the gas bubbles is larger than the diameter of the reactor. When a catalyst bed was placed into the tube, the flow exiting the bed still had distinct gas and liquid slugs but the flow was less regular after being broken up by the catalyst bed. The breaking of the gas and liquid slugs could be seen as the flow passed through the catalyst bed. The rate of mass transfer of reactants to the catalyst under Taylor flow can be assumed to be high for two reasons; firstly the liquid layer between the gas and catalyst particles is so thin that it forms a very low barrier to mass transfer of reactants to the catalyst, secondly, the liquid slugs in the reactor can circulate internally eliminating any radial concentration gradients.

The effect of common ions and organic contaminants found in drinking water on catalytic activity towards hydrogen peroxide synthesis was evaluated using a Parr Instruments stainless steel autoclave with a nominal volume of $50 \mathrm{~mL}$ and a maximum working pressure of $14 \mathrm{MPa}$. To test the catalyst for $\mathrm{H}_{2} \mathrm{O}_{2}$ synthesis, the autoclave was charged with catalyst ( $\left.0.01 \mathrm{~g}\right)$ and solvent ( $8.5 \mathrm{~g} \mathrm{H}_{2} \mathrm{O}$, HPLC grade). 
The charged autoclave was then purged three times with $5 \% \mathrm{H}_{2} / \mathrm{CO}_{2}(0.7 \mathrm{MPa})$ before filling with $5 \%$ $\mathrm{H}_{2} / \mathrm{CO}_{2}$ to a pressure of $2.9 \mathrm{MPa}$, followed by the addition of $25 \% \mathrm{O}_{2} / \mathrm{CO}_{2}(1.1 \mathrm{MPa})$. The temperature was maintained at $20^{\circ} \mathrm{C}$ using a HAAKE $\mathrm{K} 50$ bath/circulator using an appropriate coolant followed by stirring $(1200 \mathrm{rpm})$ of the reaction mixture for $0.5 \mathrm{~h} . \mathrm{H}_{2} \mathrm{O}_{2}$ concentration was determined by titrating aliquots of the final solution after reaction with acidified $\mathrm{Ce}\left(\mathrm{SO}_{4}\right)_{2}(0.01 \mathrm{M})$ in the presence of ferroin indicator.

\section{Suspension tests.}

Test bacteria were prepared following overnight incubation in tryptone soya broth at $37^{\circ} \mathrm{C}$, centrifugation at $4194 \mathrm{~g}$ and resuspension in sterile tryptone sodium chloride solution to an adjusted concentration of $10^{7} \mathrm{CFU} / \mathrm{mL}$. MS2 was propagated by mixing MS2 with its host cell Escherichia coli NCIMB 948 in a 1:1 ratio in $5 \mathrm{~mL}$ of $65 \%$ tryptone soya agar containing $5 \mathrm{mM} \mathrm{CaCl}_{2}$. The mixture was dispensed on the surface of a tryptone soya agar plate. After incubation at $37^{\circ} \mathrm{C}$ for $24 \mathrm{~h}$, the top agar layer was scraped off, centrifuged at $10,000 \mathrm{~g}$ for $15 \mathrm{~min}$ at $4{ }^{\circ} \mathrm{C}$ and the supernatant containing MS2 filtered first through a $0.45 \mu \mathrm{m}$ membrane filter and then through a $0.2 \mu \mathrm{m}$ filter. Virus concentration was adjusted to $10^{9} \mathrm{PFU} / \mathrm{mL}$. Efficacy of $\mathrm{H}_{2} \mathrm{O}_{2}$ solution was tested in a suspension test in which $1 \mathrm{~mL}$ of bacterial/viral suspension was mixed with $1 \mathrm{~mL}$ bovine serum albumin $(3 \mathrm{~g} / \mathrm{L})$ and added to $8 \mathrm{~mL}$ of test $\mathrm{H}_{2} \mathrm{O}_{2}$ solution in hard water $\left(0.114 \mathrm{~g} / \mathrm{L} \mathrm{MgCl}_{2}, 0.276 \mathrm{~g} / \mathrm{L} \mathrm{CaCl}_{2}, 0.280 \mathrm{~g} / \mathrm{L} \mathrm{NaHCO}_{3}\right)$. After 1 or 60 min contact time at $20^{\circ} \mathrm{C}, 1 \mathrm{~mL}$ of test suspension was added to $9 \mathrm{~mL}$ of a neutraliser $(20 \mathrm{~g} / \mathrm{L}$ sodium thiosulphate and $500 \mathrm{U} / \mathrm{mL}$ catalase). Aliquot of the neutralised suspension was serially diluted and 10 $\mu \mathrm{L}$ of each dilution plated in triplicate on tryptone soya agar for bacteria. After incubation at $37^{\circ} \mathrm{C}$ for $24 \mathrm{~h}$, colonies per drop were counted and bacterial viability $(\mathrm{CFU} / \mathrm{mL})$ calculated. For MS2, $100 \mu \mathrm{L}$ of each dilution was mixed with $100 \mu \mathrm{L}$ of Escherichia coli NCIMB $948\left(10^{6} \mathrm{CFU} / \mathrm{mL}\right)$ in $5 \mathrm{~mL}$ of $65 \%$ tryptone soya agar containing $5 \mathrm{mM} \mathrm{CaCl}_{2}$. The mixture was dispensed on the surface of a tryptone soya agar plate. After incubation at $37^{\circ} \mathrm{C}$ for $24 \mathrm{~h}$, plaques were enumerated. A negative control consisted in replacing the $8 \mathrm{~mL} \mathrm{H}_{2} \mathrm{O}_{2}$ solution with hard water only. Reduction in viability ( $\log _{10}$ reduction) was measured by comparing bacterial/virus number from the control and those from the $\mathrm{H}_{2} \mathrm{O}_{2}$ solutions tested. Three biological replicates were performed each with two technical replicates. Additional controls consisted in validating the efficacy of the neutraliser and the lack of neutraliser toxicity were performed according to Leggett et al. ${ }^{21}$

\section{Prevention of bacterial attachment.}

200 and 100 ppm of commercial, stabilised and flow reactor generated $\mathrm{H}_{2} \mathrm{O}_{2}$, or $\mathrm{NaOCl}(0.25,0.5,1$ and 2 ppm available. chlorine) was added to the wells of a 96 well plates. E. coli K12 JM109 (concentration adjusted to $1 \times 10^{7} \mathrm{CFU}$ taking into account the bactericidal activity of $\mathrm{H}_{2} \mathrm{O}_{2}$ or chlorine) in TSB was inoculated to each well but for the control. Negative control consisted of E. coli K12 JM109 
in TSB. Blank experiments consisted of TSB, 200, 100 of commercial, stabilised or flow reactor generated $\mathrm{H}_{2} \mathrm{O}_{2}$. The plate was incubated in a shaking incubator at $120 \mathrm{rpm}, 37^{\circ} \mathrm{C}$ for 6 hours. After 6 hours of incubation, crystal violet assay was performed ${ }^{64}$ to measure the adherence of the bacteria to the well surface. All of the treatments and controls were performed in triplicate and the experiment was performed three times independently.

\section{X-ray diffraction.}

The bulk structure of the catalysts was determined by powder X-ray diffraction using a $(\theta-\theta)$ PANalytical X'pert Pro powder diffractometer using a $\mathrm{Cu} \mathrm{K}_{\alpha}$ radiation source, operating at $40 \mathrm{keV}$ and $40 \mathrm{~mA}$. Standard analysis was carried out using a 40 min run with a back filled sample, between $2 \theta$ values of $10-80^{\circ}$. Phase identification was carried out using the International Centre for Diffraction Data (ICDD).

\section{High-angle annular dark-field scanning transmission electron microscopy.}

Scanning transmission electron microscopy (STEM) data were obtained from an aberration corrected JEOL ARM200CF microscope operated at $80 \mathrm{kV}$. The particle size distribution was obtained using ImageJ.

\section{X-ray photoelectron spectroscopy.}

X-ray photoelectron spectroscopy (XPS) analyses were made on a Kratos Axis Ultra DLD spectrometer. Samples were mounted using double-sided adhesive tape and binding energies were referenced to the C $(1$ s) binding energy of adventitious carbon contamination that was taken to be $284.8 \mathrm{eV}$. Monochromatic $\mathrm{AlK}_{\alpha}$ radiation was used for all measurements; an analyser pass energy of $160 \mathrm{eV}$ was used for survey scans, while $40 \mathrm{eV}$ was employed for more detailed regional scans. The intensities of the $\mathrm{Au}(4 \mathrm{f})$ and $\mathrm{Pd}(3 \mathrm{~d})$ features were used to derive the $\mathrm{Au} / \mathrm{Pd}$ surface composition ratios.

\section{Inductively coupled plasma mass spectrometry.}

Total metal leaching from the supported catalyst was quantified via inductively coupled plasma mass spectrometry (ICP-MS). Post-reaction solutions were analysed using an Agilent 7900 ICP-MS equipped with I-AS auto-sampler. All samples were diluted by a factor of 10 using HPLC grade $\mathrm{H}_{2} \mathrm{O}\left(1 \% \mathrm{HNO}_{3}\right.$ and $0.5 \% \mathrm{HCl}$ matrix). All calibrants were matrix matched and measured against a five-point calibration using certified reference materials purchased from Perkin Elmer and certified internal standards acquired from Agilent. Detection limits for $\mathrm{Au}$ and Pd are reported as 0.0192 and $0.048 \mathrm{ug} / \mathrm{L}$ respectively. 


\section{Electron paramagnetic resonance spectroscopy.}

The X-band CW-EPR spectra were recorded on a Bruker EMX Micro spectrometer equipped with a Bruker ER4123-D dielectric resonator, operating at room temperature. Before each measurement, samples coming from the flow reactor where deoxygenated for 20 min under $\mathrm{N}_{2}$ flow and transferred into a Q-band EPR tube (1.6 mm outer diameter, $1.1 \mathrm{~mm}$ inner diameter suprasil tube, product number: WG-222T-RB Wilmad Labglass). Experimental spectra were simulated using the EasySpin package ${ }^{65}$ operating within the Mathworks Matlab environment.

\section{Data availability.}

The data supporting the findings of this study are available within the article and its Supplementary Information, with the underlying data found at the Cardiff University Data Repository via http://doi.org/10.17035/d.2021.0132824835.

\section{References.}

1 Lewis, R. J. \& Hutchings, G. J., Recent Advances in the Direct Synthesis of $\mathrm{H}_{2} \mathrm{O}_{2}$. ChemCatChem 11, 298-308, (2019).

2 Freakley, S. J. et al., Palladium-tin catalysts for the direct synthesis of $\mathrm{H}_{2} \mathrm{O}_{2}$ with high selectivity. Science 351, 965-968, (2016)..

3 Wilson, N. M., Priyadarshini, P., Kunz, S. \& Flaherty, D. W., Direct synthesis of $\mathrm{H}_{2} \mathrm{O}_{2}$ on $\mathrm{Pd}$ and AuxPd1 clusters: Understanding the effects of alloying Pd with Au. J. Catal., 357, 163175, (2018).

4 Edwards, J. K. et al., Switching off hydrogen peroxide hydrogenation in the direct synthesis process. Science 323, 1037-1041, (2009).

5 Edwards, J. K. et al., Direct synthesis of hydrogen peroxide from $\mathrm{H}_{2}$ and $\mathrm{O}_{2}$ using $\mathrm{TiO}_{2}$ supported Au-Pd catalysts. J. Catal., 236, 69-79, (2005).

6 Ntainjua, E.N, et al., The role of the support in achieving high selectivity in the direct formation of hydrogen peroxide. Green Chem., 10, 1162-1169, (2008).

7 Pritchard, J. et al., Direct Synthesis of Hydrogen Peroxide and Benzyl Alcohol Oxidation Using Au-Pd Catalysts Prepared by Sol Immobilization. Langmuir 26, 16568-16577, (2010).

8 Wilson, N. M \& Flaherty, D. W., Mechanism for the Direct Synthesis of $\mathrm{H}_{2} \mathrm{O}_{2}$ on Pd Clusters: Heterolytic Reaction Pathways at the Liquid-Solid Interface. J. Am. Chem. Soc. 138, (2016).

9 Li, J., Ishihara, T. \& Yoshizawa, K., Theoretical Revisit of the Direct Synthesis of $\mathrm{H}_{2} \mathrm{O}_{2}$ on Pd and Au@Pd Surfaces: A Comprehensive Mechanistic Study. J. Phys. Chem. C, 115, 2535925367, (2011). 
10 Climate Change and Water, United Nations Water Policy Brief available from https://www.unwater.org/publications/un-water-policy-brief-on-climate-change-and-water/

11 Larsen, T.A., Hoffmann, S., Luthi, C., Truffer, B., \& Maurer M., Emerging solutions to the water challenges of an urbanizing world. Science, 352, 928-933, (2016).

12 Grant S.B. et al., Taking the "waste" out of "wastewater" for human water security and ecosystem sustainability. Science, 337, 681-686 (2012).

13 Li, H., Zhu, X. \& Ni, J., Comparison of electrochemical method with ozonation, chlorination and monochloramination in drinking water disinfection. Electrochim. Acta. 56, 9789-9796, (2011).

14 Nieuwenhuijsen, M. J., Toledano, M. B., Eaton, N. E., Fawell, J. \& Elliott, P., Chlorination disinfection byproducts in water and their association with adverse reproductive outcomes: a review. Occup. Environ. Med. 57, 73, (2000).

15 Huang, X. et al., Electrochemical disinfection of toilet wastewater using wastewater electrolysis cell. Water Res. 92, 164-172, (2016).

16 Xie, Y. Disinfection Byproducts in Drinking Water: Formation, Analysis, and Control., (Taylor \& Francis, 2003).

17 Xia, C., Xia, Y., Zhu, P., Fan, L. \& Wang, H., Direct electrosynthesis of pure aqueous $\mathrm{H}_{2} \mathrm{O}_{2}$ solutions up to $20 \%$ by weight using a solid electrolyte. Science 366, 226-231, (2019).

18 Tapping into the efficiency of hydrogen peroxide for water treatment available from https://www.solvay.com/en/article/hydrogen-peroxide-for-water-treatment.

19 S. S. Block, Disinfection, sterilization and preservation. (Lippincott Williams \& Wilkins, ed. 5, 2003) pp. 185-204.

20 Linley, E., Denyer, S.P., McDonnell, G., Simons, C. \& Maillard, J-Y., Use of hydrogen peroxide as a biocide: new consideration of its mechanisms of biocidal action. J. Antimicrob. Chemother. 67, 1589-1596, (2012).

21 Leggett, M. J. et al., Mechanism of sporicidal activity for the synergistic combination of peracetic acid and hydrogen peroxide. Appl. Environ. Microbiol., 82, 1035-1039. (2016).

22 Finnegan, M, et al., Mode of action of hydrogen peroxide and other oxidizing agents: differences between liquid and gas forms. J. Antimicrob. Chemother. 65, 2108-2115, (2010).

23 Jung, Y., Park, J. Y., Ko, S. O. \& Kim, Y., H Stabilization of hydrogen peroxide using phthalic acids in the Fenton and Fenton-like oxidation. Chemosphere 90, 812-819, (2013).

24 W. Schumb, Stabilization of Concentrated Solutions of Hydrogen Peroxide. Ind. Eng. Chem. 49, 1759-1762, (1957).

25 Underhill, R. et al., Oxidative Degradation of phenol using in-situ generated $\mathrm{H}_{2} \mathrm{O}_{2}$ combined with Fenton's process. Johnson Matthey Technol. Rev.62, 417-425 (2018).

26 Santos, A. et al., Direct Synthesis of Hydrogen Peroxide over Au-Pd Supported Nanoparticles under Ambient Conditions. Ind. Eng. Chem. Res. 58, 12623-12631, (2019). 
27 García, $\mathrm{T}$ et al., Enhanced $\mathrm{H}_{2} \mathrm{O}_{2}$ production over Au-rich bimetallic Au-Pd nanoparticles on ordered mesoporous carbons. Catal. Today 248, 48-57, (2015).

28 Samanta, C. \& Choudhary, V. R. Direct synthesis of $\mathrm{H}_{2} \mathrm{O}_{2}$ from $\mathrm{H}_{2}$ and $\mathrm{O}_{2}$ over $\mathrm{Pd} / \mathrm{H}$-beta catalyst in an aqueous acidic medium: Influence of halide ions present in the catalyst or reaction medium on $\mathrm{H}_{2} \mathrm{O}_{2}$ formation. Catal. Commun., 8, 73-79, (2007).

29 European Standard (2019) BS EN1276:2019: Chemical disinfectants and antiseptics. Quantitative suspension test for the evaluation of bactericidal activity of chemical disinfectants and antiseptics used in food, industrial, domestic and institutional areas. Test method and requirements.

30 Freakley, S. J. et al. Effect of Reaction Conditions on the Direct Synthesis of Hydrogen Peroxide with a AuPd/TiO 2 Catalyst in a Flow Reactor. ACS Catal., 3, 487-501, (2013).

31 Ford, D. C, Nilekar, A. U., Xu, Y. \& Mavrikakis, M. Partial and complete reduction of $\mathrm{O}_{2}$ by hydrogen on transition metal surfaces. Surf. Sci. 604, 1565-1575, (2010).

32 Ronen, Z., Guerrero, Z. A. \& Gross, A. Greywater disinfection with the environmentally friendly Hydrogen Peroxide Plus (HPP). Chemosphere 78, 61-65, (2010).

33 Scoville, J. R., Novicova, I. A., (Cottrell Ltd.), US 5900256, (1996).

34 P.Wegner, (Wegner Paul C.), US20050065052 A1, (2003).

35 Mazzola, P. G., Penna, T. C. V. \& da S Martins, A. M., Determination of decimal reduction time (D value) of chemical agents used in hospitals for disinfection purposes. BMC Infect. Dis., 3, 24, (2003).

36 Watts, M. J. \& Linden, K. G. Chlorine photolysis and subsequent $\mathrm{OH}$ radical production during UV treatment of chlorinated water. Water Res., 41, 2871-2878, (2007).

37 Lillard, S. H., \& Thomson, J. E., Efficacy of Hydrogen Peroxide as a Bactericide in Poultry Chiller Water. J. Food Sci. 48, 125-126, (1983).

38 Xia, D. et al. Enhanced photocatalytic inactivation of Escherichia coli by a novel Z-scheme g$\mathrm{C}_{3} \mathrm{~N}_{4} / \mathrm{m}-\mathrm{Bi}_{2} \mathrm{O}_{4}$ hybrid photocatalyst under visible light: The role of reactive oxygen species. Appl. Catal., B, 214, 23-33, (2017).

39 Spuhler, D., Andrés Rengifo-Herrera, J. \& Pulgarin, C., The effect of $\mathrm{Fe}^{2+}, \mathrm{Fe}^{3+}, \mathrm{H}_{2} \mathrm{O}_{2}$ and the photo-Fenton reagent at near neutral $\mathrm{pH}$ on the solar disinfection (SODIS) at low temperatures of water containing Escherichia coli K12. Appl. Catal., B, 96, 126-141, (2010).

40 Abidi, M. et al., Simultaneous removal of bacteria and volatile organic compounds on $\mathrm{Cu}_{2} \mathrm{O}-$ NPs decorated $\mathrm{TiO}_{2}$ nanotubes: Competition effect and kinetic studies. J. Photochem. Photobiology., A, 400, (2020).

41 Murphy, H. M., Payne, S. J. \& Gagnon, G. A., Sequential UV- and chlorine-based disinfection to mitigate Escherichia coli in drinking water biofilms. Water Res., 42, 2083-2092, (2008).

42 Zhao, Y. et al., Removal of Escherichia Coli from water using functionalized porous ceramic disk filter coated with $\mathrm{Fe} / \mathrm{TiO}_{2}$ nano-composites. J. Water Process. Eng., 33, 101013, (2020). 
43 Clark, T., Dean, B., Watkins, S. E, Evaluation of Different Hydrogen Peroxide Products for Maintaining Adequate Sanitizing Residual in Water. Avian Advice, 11, 1-3, (2009).

44 Sobsey, M. D. Inactivation of Health-Related Microorganisms in Water by Disinfection Processes. Water Sci. Technol. 21, 179-195, (1989).

45 Ferris, R. A. et al. In Vitro Efficacy of Nonantibiotic Treatments on Biofilm Disruption of Gram-Negative Pathogens and an In Vivo Model of Infectious Endometritis Utilizing Isolates from the Equine Uterus. J. Clin. Microbiol. 54, 631-639, (2016).

46 Cho, M., Chung, H., Choi, W. \& Yoon, J. Linear correlation between inactivation of E. coli and $\mathrm{OH}$ radical concentration in $\mathrm{TiO} 2$ photocatalytic disinfection. Water Res., 38, 1069-1077, (2004).

47 P. Lukes, B.R. Locke, J.-L. Brisset Aqueous-phase chemistry of electrical discharge plasma in water and in gas-liquid environments V.I. Parvulescu, M. Magureanu, P. Lukes (Eds.), Plasma Chemistry and Catalysis in Gases and Liquids, Wiley-VCH Verlag GmbH \& Co. KGaA, Germany (2012), pp. 243-308

48 Keyer, K. \& Imlay, J. A. Superoxide accelerates DNA damage by elevating free-iron levels. Proc. Natl. Acad. Sci.U.S.A, 93, 13635-13640, (1996).

49 Pinto, E. et al. Heavy metal-induced oxidative stress in algae., J. Phycol. 39, 1008-1018, (2003).

50 Pizzorno, J. Glutathione! Integr. Med. (Encinitas) 13, 8-12 (2014).

51 Sankar, M. et al. Synthesis of Stable Ligand-free Gold-Palladium Nanoparticles Using a Simple Excess Anion Method. ACS Nano 6, 6600-6613, (2012).

52 Ouyang, L. et al. The origin of active sites for direct synthesis of $\mathrm{H}_{2} \mathrm{O}_{2}$ on $\mathrm{Pd} / \mathrm{TiO}_{2}$ catalysts: Interfaces of Pd and PdO domains. J. Catal., 321, 70-80, (2015).

53 Gong, X. et al. Enhanced catalyst selectivity in the direct synthesis of $\mathrm{H}_{2} \mathrm{O}_{2}$ through $\mathrm{Pt}$ incorporation into $\mathrm{TiO}_{2}$ supported AuPd catalysts. Catal. Sci. Technol.,10, 4635-4644, (2020).

54 Buettner, G. R. Spin Trapping: ESR parameters of spin adducts 1474 1528V. Free Radical Biol. Med., 3, 259-303, (1987).

55 Kiwi, J. \& Nadtochenko, V., Evidence for the Mechanism of Photocatalytic Degradation of the Bacterial Wall Membrane at the $\mathrm{TiO}_{2}$ Interface by ATR-FTIR and Laser Kinetic Spectroscopy., Langmuir 21, (2005).

56 Anbar, M., Meyerstein, D. \& Neta, P. Reactivity of aliphatic compounds towards hydroxyl radicals. J. Chem. Soc. B., 742-747, (1966).

57 Billany, M. R., Khatib, K., Gordon, M. \& Sugden, J. K., Alcohols and ethanolamines as hydroxyl radical scavengers. Int. J. Pharm., 137, 143-147, (1996).

58 Palluy, O., Bonne, C. \& Modat, G., Hypoxia/reoxygenation alters endothelial prostacyclin synthesis-Protection by superoxide dismutase. Free Radical Biol. Med., 11, 269-275, (1991).

59 Hayyan, M., Hashim, M. A. \& AlNashef, I. M. Superoxide Ion: Generation and Chemical Implications. Chem. Rev., 116, 3029-3085, (2016). 
60 Chelikani, P., Fita, I. \& Loewen, P. C. Diversity of structures and properties among catalases. Cell. Mol. Life Sci., 61, 192-208, (2004).

61 Finkelstein, E., Rosen, G. M., Rauckman, E. J., \& Paxton, J. Spin Trapping of Superoxide. Mol. Pharmacol. 16, 676, (1979).

62 Finkelstein, E., Rosen, G. M. \& Rauckman, E. J. Production of hydroxyl radical by decomposition of superoxide spin-trapped adducts. Mol. Pharmacol. 21, 262-265 (1982).

63 Lewis, R. J. et al. The Direct Synthesis of $\mathrm{H}_{2} \mathrm{O}_{2}$ Using TS-1 Supported Catalysts. ChemCatChem, 11, 1673-1680, (2019).

64 Simoes, L .C., Simoes, M. and Vieira, M.J, Biofilm Interactions between Distinct Bacterial Genera Isolated from Drinking Water. Appl. Environ. Microbiol. 73, 6192-6200 (2007).

65 Stoll, S. \& Schweiger, A. EasySpin, a comprehensive software package for spectral simulation and analysis in EPR. J. Magn. Reson. 178, $42-55$ (2006).

\section{Acknowledgements.}

The authors wish to acknowledge the research discussion with Dŵr Cymru Welsh Water and the Cardiff University electron microscope facility for the transmission electron microscopy. S.J.F., R.J.L. and G.J.H. gratefully acknowledge Cardiff University for financial support as part of the MAXNET Energy Consortium, in addition SJF acknowledges the award of a Prize Research Fellowship from the University of Bath. D.A.C acknowledges Selden Research Limited. JYM and GMS thank Laboratoires Anios for funding. GH thanks the EPSRC (EP/F008538/1) for funding. QH would like to acknowledge the support by National Research Foundation (NRF) Singapore, under its NRF Fellowship (NRFNRFF11-2019-0002).

\section{Author Contributions.}

T.R, J.H.H., R.J.L, AG.R.H, G.M.S, A.F., J.K.E, D.M.M., J.Y.M, S.J.F and G.J.H contributed to the design of the study; T.R, J.H.H., R.J.L, AG.R.H, G.M.S, E.J.L, D.A.C and S.J.F conducted experiments and data analysis. R.J.L, AG.R.H, A.F., J.K.E, P.G., C.J.K, D.M.M., J.Y.M, S.J.F and G.J.H provided technical advice and result interpretation. D.J.M, T.E.D, C.J.K, and Q.H conducted catalyst characterisation and corresponding data processing. R.J.L, A.F., J.Y.M., S.J.F and G.J.H wrote the manuscript; R.J.L, A.F. and S.J.F wrote the electronic supplementary information, all authors commented on and amended both documents. All authors discussed and contributed to the work.

\section{Competing Interests.}

All authors declare no competing interests.

\section{Supplementary Information.}

Supplementary Figures 1-25, Tables 1-3, Notes 1-3 and References. 
Source Data Fig. 2

Statistical Source Data

Source Data Fig. 3

Statistical Source Data 